\title{
Simultaneous use of strontium:calcium and barium:calcium ratios in otoliths as markers of habitat: Application to the European eel (Anguilla anguilla) in the Adour basin, South West France
}

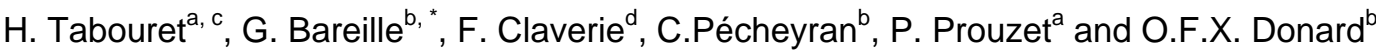

\author{
a IFREMER Laboratoire des Ressources Halieutiques d'Aquitaine, UFR côte Basque, 1 Allée du Parc Montaury, \\ 64600 Anglet, France \\ ${ }^{\mathrm{b}}$ Laboratoire de Chimie Analytique Bio-inorganique et Environnement, UMR 5254 CNRS/UPPA - IPREM, \\ Hélioparc Pau Pyrénées, 64053 Pau Cedex 9, France \\ ${ }^{c}$ Département Milieux et peuplements Aquatiques, biologie des Organismes et Ecosystèmes Aquatiques (UMR \\ CNRS-MNHN 7208), Muséum National d'Histoire Naturelle, 43 Rue Cuvier, 75005 Paris, France \\ ${ }^{d}$ National Institute of Standards and Technology (NIST), Gaithersburg, MD 20899, USA \\ *: Corresponding author : G. Bareille, Tel.: +33 05594077 61; fax: +33 05594077 80, email address : \\ gilles.bareille@univ-pau.fr
}

\begin{abstract}
:
$\mathrm{Sr}: \mathrm{Ca}$ and $\mathrm{Ba}: \mathrm{Ca}$ ratios in water from the Adour estuary show a clear relationship with the salinity of the surrounding water for salinities $<20$, while ratios are almost constant above this level of salinity. A positive relationship was observed for the Sr:Ca ratio, whereas it was inverse for the Ba:Ca ratio. These two elemental ratios were measured in the otoliths of the European eels (Anguilla anguilla L.) using femtosecond laser ablation linked to an ICP-MS (fs-LA-ICP-MS). There was a direct relationship between the elemental ratios recorded in eel otoliths and those found in water from fresh and marine areas, suggesting that $\mathrm{Sr}: \mathrm{Ca}$ and $\mathrm{Ba}: \mathrm{Ca}$ ratios in eel otoliths can be used as markers of habitat in this estuary. Continuous profiling allowed the determination of three behaviour patterns in terms of habitat: freshwater, estuary and migratory individuals. Finally, the above results support the simultaneous use of both ratios for a better understanding of the migratory contingents and also as a relevant method to avoid a misidentification of environmental migratory history due to the presence of vaterite crystal in the otolith matrix.
\end{abstract}

Keywords: Otoliths; Anguilla anguilla; Estuaries; Water chemistry; Strontium; Barium; Laser ablation; Inductively coupled plasma mass spectrometer 


\section{Introduction}

The European eel Anguilla anguilla L. is a high migratory catadromous fish. Leptocephali larvae are transported by the Gulf Stream from the hypothetic spawning ground in the Sargasso Sea (Schmidt, 1922) throughout its distribution area towards the European and North African coasts. Near to the continental shelf, a first metamorphosis takes place giving glass eels which colonize inland and coastal waters. After a growing period of 3 to 15 years depending on their sex, yellow eels undergo a second metamorphosis, they change into silver eels and emigrate into the Atlantic where the sexual maturation occurs. European eel populations have significantly declined throughout their distribution area since the 1980s (Moriarty and Dekker, 1997). In 2007, the European Council Regulation (CE $1100 / 2007$ ) for the recovery of eel stocks required the management of eel populations at a local scale, level corresponding to hydrographic basin. At this local level, recent publications have shown that eels are not strict catadromous fish and exhibit a mosaic of habitat use during the growing phase inside a single hydrographic system i.e. strict marine residency, strict freshwater residency, migrations from freshwater habitats to marine habitats and vice versa (Daverat et Tomas, 2006; Tsukamoto and Arai, 2001; Tzeng et al., 2000). In the Adour basin (South West, France), glass eel fisheries in 2000 represented $80 \%$ of the figure for the local fishermen's business (Prouzet, 2002) showing the economic importance of this species and its management in this area. In order to better understand the habitat use and the probable interaction between eels and anthropogenic activities (pollution, fisheries, dams...) along the Adour estuary, investigations were conducted using the potential of geochemical indicators in the otoliths to reconstruct life history.

Otoliths are well known calcified structures, metabolically inert and continuously growing throughout life, consisting of successive discrete layers of aragonite crystalline microstructure corresponding to daily growth increments (Campana and Thorrold, 2001) deposited on a protein matrix. These layers called annuli are able to trap minor and trace elements within the matrix during the calcification process. In combination with age data, otolith elemental composition has been used to reconstruct migratory environmental history of fish (Elfman et al., 2000; Halden et al., 2000; Daverat et al., 2005; Shiao et al., 2006; Arai et al., 2007). Among elements trapped in the otolith, strontium (Sr), particularly the Sr:Ca ratio, is the most common marker used to describe migratory environmental history of diadromous and catadromous fish (Limburg et al., 2001; Milton et al., 2008), particularly European and Japanese eels (Tzeng et al., 1997; Shiao et al., 2006). On the French coast, Daverat and Tomas (2006) highlighted more than 6 behaviour patterns of European eel in the Gironde-Dordogne-Garonne system based on the analysis of strontium otolith composition. In order to check for the mosaic of habitat use in the Adour estuary and associated watersheds, analysis of $\mathrm{Sr}$ composition in yellow eel otoliths was assessed using LA-ICP-MS (laser ablation - inductively coupled plasma - mass spectrometry). This method allows the quantitatively determination of trace and minor elements within otolith at a high spatial resolution (Coutant and Chen, 2003; Arai and Hirata, 2006; Chu et al., 2007). However, the use of $\mathrm{Sr}$ for the reconstruction of the individual history exhibits some limitations. First, variations in ambient chemistry over time, of the water masses in question have to show significant and consistent differences in ambient strontium levels. Chemical signatures inside the water mass also have to 
be stable over time to ensure that variations incorporated within the otolith matrix reflect or physiological changes or migration of the individual between different water masses. Finally, the accurate reconstitution of habitat histories depends upon the occurrence of vaterite inclusions, one of the three natural polymorphs of $\mathrm{CaCO}_{3}$ (calcite, aragonite and vaterite). Indeed, vaterite was shown to trap less $\mathrm{Sr}$ than aragonite (Brown and Severin, 1999; Melancon et al., 2005; Tzeng et al., 2007), resulting in elemental composition not related to the ambient water chemistry leading in a misidentification of habitat use and historical migration (Tzeng et al., 2007; Jessop et al., 2008).

In the following report, we propose the use of $\mathrm{Sr}$ as an environmental marker to reconstruct the habitat use of eels in the Adour estuary and associated wetlands. However, in order to overcome the limitations of the presence of vaterite, we propose the association of strontium with barium. Recent findings (McCulloch et al., 2003; Elsdon and Gillanders, 2005a; Hamer et al., 2006) have underlined the potential of the Ba:Ca ratio to track environmental histories of fish, due to the ability of an element such as $\mathrm{Sr}$ to be incorporated into otoliths primarily in relation to ambient concentrations (Bath et al., 2000; Milton and Chenery, 2001; Elsdon and Gillanders, 2004; de Vries et al., 2005). Furthermore, McCulloch et al. (2005) highlighted the strong inverse correlation between $\mathrm{Sr}: \mathrm{Ca}$ and $\mathrm{Ba}: \mathrm{Ca}$ in barramundi (Lates calcarifer) aragonitic otolith whereas both ratios were shown to have similar pattern in vateritic otolith (Tzeng et al., 2007). As a first step, we propose the comparison of ambient water chemistry in the freshwater and marine waters of the Adour estuary to assess if concentration gradients exist for both $\mathrm{Sr}: \mathrm{Ca}$ and $\mathrm{Ba}: \mathrm{Ca}$ ratios in this region. Relation between otolith incorporation and water chemistry was then assessed by Comparing the $\mathrm{Ba}: \mathrm{Ca}$ and $\mathrm{Sr}: \mathrm{Ca}$ ratios determined from eel (Anguilla anguilla) otoliths with water samples. Finally, we tested the reliability of using both elemental ratios recorded from individual otoliths to describe the life history of eels in the Adour estuary and the associated wetlands avoiding possible error caused particularly by the presence of vaterite inclusions.

\section{Materials and Methods}

\subsection{Fish sampling}

Yellow eel sampling was conducted at four sites in the Adour basin (South West, France) that represent two extremes of water masses: saline and the strictly freshwater environment upstream (Fig. 1). Intermediate water masses were unfortunately not sampled due to the opportunist character of our sampling which was based on two fish population monitoring programs one located in the upstream wet zone of the estuary and the other one in lower part of the estuary. The first site, sampled in July 2005 and July 2007, is situated near the estuary mouth (Redon, $\mathrm{N}=14$ ) where the influence of marine waters is marked at the bottom with salinity usually between 25 and 35, but around 10 - 20 during specific tide and flow conditions. Two wetlands corresponding to floodplains and located closed to the upper limit of the saline intrusion were also sampled: one directly connected to the Adour river and subjected to the influx of brackish waters only during spring tides and low flow (St Laurent de Gosse, SLG, N=14) and a second one connected to the Adour river by a tributary, showing brook characteristics (Termi, $N=49$ ) and never affected by saline water. Samples were collected five times between October 
2005 and July 2007 at these two sites by electrofishing. Finally, a couple of individual fish were collected only once in the Gave de Pau river (Cauneille, $N=4$ ), one of the three major tributaries of the Adour estuary, outside the influence of the dynamic tide.

\subsection{Water chemistry}

Spatial variability in water chemistry $(\mathrm{Ca}, \mathrm{Sr}, \mathrm{Ba})$ was investigated across the mixing zone of the Adour estuary, within different freshwater tributaries and wetlands where eels were collected (Fig. 1). Water samples were collected twice at the eel freshwater sampling sites (Fig. 1), on $5^{\text {th }}$ September 2007 and $26^{\text {th }}$ June 2008. To assess the spatial variation in water chemistry in the Adour estuary, the entire salinity gradient was also sampled on the same date, September 2007 and June 2008. Additional Ba water chemistry data were also obtained in the saline mixing zone as in the coastal zone using unpublished previous measurements (February and July 1998) and new sampling dates (April and June 2007). In 1998 and 2007, sampling was performed thanks to an ultra trace Go Flo Teflon coated sampler (General Oceanic) on the French oceanographic vessels "Côte d'Aquitaine" and "Côte de la Manche" (CNRS/INSU). Temporal variability in water chemistry during an annual hydrological cycle was checked on the Gave de Pau, a major tributary of the Adour River, based on a weekly sampling strategy from March to October 2007.

Most of the water samples used in this study were collected at subsurface and were processed using ultra-clean protocol as previously published in Point et al. (2007). In the lower estuary where a strong stratification of the water column is observed (Dailloux, 2008), water samples were also taken across the water column during some dates. No significant difference was found between vertical and horizontal concentrations of dissolved trace elements compared to salinity, particularly for $\mathrm{Ba}$ as for the other elements. Thereby, water samples collected directly below the surface, in the mixing zone of the estuary, were considered to be representative of the water chemistry variability experienced by eel at the bottom in the downstream estuary.

$\mathrm{Sr}$ and $\mathrm{Ba}$ concentrations were measured in freshwater and marine water samples using an X7 series CCT ICP-MS (Thermo Electron, Windsford, UK). Marine water samples were diluted to obtain salt content below $2 \mathrm{~g} \mathrm{~L}^{-1}$ prior to the analysis. Internal standard of Indium $\left(2 \mu \mathrm{g} \mathrm{L}^{-1}\right)$ was used to correct for instrument drift. Ca was determined using ICP-AES (Inductively Coupled Plasma Atomic Emission Spectrometry - PANORAMA, Horiba Jobin Yvon). Blanks were regularly performed, using the same protocol as for the samples, with $18.2 \mathrm{M} \Omega \mathrm{MQ}$ water (Millipore). The general performance of the procedure was checked using the certified reference freshwater SLRS-4 (NRCC, Canada) or the CASS-4 (NRCC, Canada), the latter being doped with $\mathrm{Ba}$ and $\mathrm{Sr}$ and diluted in the same manner as the samples. Mean Sr:Ca and Ba:Ca ratios $\left(\mu \mathrm{g} \mathrm{g}^{-1}\right)$ were calculated for each site. However, due to a lack of samples from the two wetland areas, an overall average was established for freshwater and for the marine water $(>20)$ end-members. 


\subsection{Otolith preparation and determination of $\mathrm{Sr}: \mathrm{Ca}$ and $\mathrm{Ba}: \mathrm{Ca}$ ratio by fs $\mathrm{LA}-$ ICP-MS analysis}

Sagittal otolith pairs were excised from the fish, cleaned according to Jones and Chen (2003) with $\mathrm{H}_{2} \mathrm{O}_{2}$ (ultrex), rinsed with $18.2 \mathrm{M} \Omega \mathrm{MQ}$ water and dried. They were embedded in araldite resin (araldite DBF CH Escil, Chassieu, France), ground on a sagittal plan to expose their cores and polished with diamond paper of decreasing grain diameter $(9.0,3.0$ and $0.1 \mu \mathrm{m})$ (Escil, Chassieu, France). Finally, the otoliths were rinsed with 18.2 $\mathrm{M} \Omega \mathrm{MQ}$ water and dried prior to the laser ablation-ICP-MS analysis.

Otolith samples were analysed with an IR $1030 \mathrm{~nm}$ femtosecond laser (AlfametNovalase, France) in conjunction with an Elan DRC II (Perkin Elmer). A linear raster scan ablation (width: $80 \mu \mathrm{m}$ ) was taken along the longest radius of the otolith. The laser beam, applied with a $500 \mathrm{~Hz}$ frequency, is rapidly moved by a back and forth displacement along the axis parallel to the annuli (y axis; speed 1 $\mathrm{mm} \mathrm{s}^{-1}$ ) while the otolith was slowly advanced in the perpendicular direction (x axis; speed $5 \mu \mathrm{m} \mathrm{s}^{-1}$ ). This leads to a $\mathrm{N}$ shaped scan formed by the partly overlapped pulses of $20 \mu \mathrm{m}$ ( $87 \%$ in the $y$ axis and $94 \%$ in the $x$ axis) and results over a whole ablated surface of a desired transect of $80 \mu \mathrm{m}$ ( $\mathrm{y}$ axis) whose length depends on the sagittal otolith size ( $x$ axis). The raster scan is taken from one edge to the other edge passing through the nucleus (Fig. 2). This allows two independent transects to be examined that would help in the identification of possible perturbations resulting from the crossing of vaterite inclusions.

One (or both) of the two transects was selected in order to determine chronological variation of ${ }^{86} \mathrm{Sr}$ and ${ }^{138} \mathrm{Ba}$. A pre cleaning ablation, consisting in a very fast $(50 \mu \mathrm{m}$ $\left.\mathrm{s}^{-1}\right)$ ablation and removing the outermost surface $(\sim 2 \mu \mathrm{m})$, was applied in order to avoid contamination of the sample surface (Wyndham et al., 2004). Table 1 gives the characteristics of the ablation and the coupling. Analytical accuracy was achieved with the fish otolith certified reference material $n^{\circ} 22$ (National Institute for Environmental Studies, Japan) (Yoshinaga et al., 2000). ${ }^{43} \mathrm{Ca}$ was used as an internal standard for each ablation to check for variation in ablation yield. Strontium and barium were standardised to calcium (i.e. $\mathrm{Sr}: \mathrm{Ca}$ and $\mathrm{Ba}: \mathrm{Ca}$ ) based on the stoichiometry of calcium carbonate (400 $000 \mu \mathrm{g} \mathrm{Ca} \mathrm{g}^{-1}$ otolith), as these elements can substitute for calcium in the otolith matrix (Campana, 1999). Quantification of ${ }^{86} \mathrm{Sr}$ and ${ }^{138} \mathrm{Ba}$ concentration were allowed with the use of a standard curve based on the analysis of calcite pellets (Barats et al., 2007). The average detection limit based on three standard deviations (SD) of the blank gas was $767 \mathrm{ng} \mathrm{g}^{-1}$ for ${ }^{86} \mathrm{Sr}$ and $32 \mathrm{ng} \mathrm{g}^{-1}$ for ${ }^{138} \mathrm{Ba}$.

After the laser ablation, the otoliths were etched with EDTA 5\% (Ultra grade, Fluka). A first observation of the otoliths by stereomicroscopy (x50) (Optech, Sodipro, France) under reflected light was carried out in order to check the presence of vaterite inclusions that appear opaque under these conditions (Tzeng et al., 2007). In the second step, the otoliths were stained with Toluidine blue 5\% (Standard, Fluka). Finally, annual growth layers, and particularly the annual growth stop mark, revealed by this coloration were observed by stereomicroscopy (x50) and counted to estimate individual age (Berg, 1985; Svedang et al., 1998). 


\subsection{Relationships between water chemistry and otolith $\mathrm{Sr}: \mathrm{Ca}$ and Ba:Ca ratios}

In order to examine the relationship between otolith microchemistry and water chemistry, the mean individual elemental ratios ( $\mathrm{Sr}: \mathrm{Ca}$ and $\mathrm{Ba}: \mathrm{Ca} ; \mu \mathrm{g} \mathrm{g}^{-1}$ ) and the averages of all water samples within each site were compared. Mean otolith Sr:Ca and $\mathrm{Ba}: \mathrm{Ca}$ values were calculated for each otolith using the portion of individual profile out of the elver mark up to the edge. Previous to this step, erratic peaks on otolith elemental profiles defined as peaks greater than 3 times the standard deviation of the mean were excluded from the calculation. Eel data from freshwater sites were compared to mean freshwater elemental ratios comprising all freshwater sites data (SLG, Termi, GP), whereas data from eels caught in the estuary were compared to data from the estuary water.

Mean elemental ratios from water ( $\left.\mathrm{Me} / \mathrm{Ca}_{\text {water }}\right)\left(\mu \mathrm{g} \mathrm{g}^{-1}\right)$ and otolith $(\mathrm{Me} / \mathrm{Ca}$ otolith $)(\mu \mathrm{g}$ $\mathrm{g}^{-1}$ ) were also used to calculate partition coefficients for $\mathrm{Sr}\left(D_{\mathrm{Sr}}\right)$ and $\mathrm{Ba}\left(D_{\mathrm{Ba}}\right)$ described as:

$\mathrm{D}_{\mathrm{Me}}=[\mathrm{Me} / \mathrm{Ca}]_{\text {otolith }} /[\mathrm{Me} / \mathrm{Ca}]_{\text {water }}$ (Morse and Bender, 1990).

Partition coefficients allow the evaluation of elemental discrimination in the otolith compared to the ambient water chemistry. $D_{\text {Me }}$ was estimated for each site taking into account mean individual elemental ratio in the otolith and mean elemental ratio in the water for the site where the individual was caught. The partition coefficient for the whole freshwater environment was calculated as the average of $D_{\mathrm{Me}}$ from all freshwater eels (SLG, Termi, Gave de Pau).

All the elemental means were expressed within a 95\% confidence interval. Differences in elemental ratio in water and otolith between sites were tested using non-parametric Kruskal Wallis test, Bravais Pearson tests were also performed to confirm the correlation between otolith and water data (XIstat-Pro 7.5.2 ; Addinsoft, France).

\subsection{Qualitative presence of vaterite inclusions as perturbation of continuous elemental profiles}

Deficiency in both $\mathrm{Sr}: \mathrm{Ca}$ and $\mathrm{Ba}: \mathrm{Ca}$ ratios in vaterite sections compared to aragonite (Brown and Severin, 1999 ; Melancon et al., 2005; Tzeng et al., 2007; Jessop et al., 2008) was used to discriminate possible affected regions in the otolith ablated sections. As in eel otoliths, both $\mathrm{Sr}: \mathrm{Ca}$ and $\mathrm{Ba}: \mathrm{Ca}$ ratios have been shown to be 7 times lower in vaterite than in aragonite (Tzeng et al., 2007), we visually checked for concomitant and drastic decrease in both $\mathrm{Sr}: \mathrm{Ca}$ and $\mathrm{Ba}: \mathrm{Ca}$ ratios from the two transects performed on both sides of the nucleus as indicative of possible vaterite inclusions. Because of the otolith asymmetry giving one transect longer than the other, and thus differential elemental dilutions during the analysis (depending on carbonate increments, analytic sampling and resolution), each side of the otolith nucleus was regarded as an independent profile. Furthermore, as vaterite crystal could be present across the whole ablated sections, mean elemental ratios calculated for individual otoliths were also compared to previously published $\mathrm{Sr}: \mathrm{Ca}$ and $\mathrm{Ba}: \mathrm{Ca}$ ratios in vaterite crystal from European eels Anguilla Anguilla (Tzeng et al., 2007). Vaterite inclusions appear darker than aragonite under reflected light after 5\% EDTA etching (Tzeng et al., 
2007) and can be easily differentiated by optical microscopy. Finally, since the otoliths were etched with 5\% EDTA for the age estimation, the presence of large vaterite inclusions along the otolith ablated profiles was also checked for.

\section{Results}

3.1. Sr: $\mathrm{Ca}$ and $\mathrm{Ba}: \mathrm{Ca}$ ratios in water bodies of the Adour estuary (freshwater, marine waters and salinity gradient)

Regarding elemental ratio $\left(\mu \mathrm{g} \mathrm{g}^{-1}\right)$, the Sr:Ca ratio points to a linearly increasing trend between salinity $>0.5 \%$ and $\leq 20 \%$ (Fig. $3 a$ ) as $\mathrm{Ba}$ :Ca shows a linearly decreasing trend (Fig. 3b) for the same salinity interval $(r=-0.806 ; P<0.0001)$. These contrasting and opposite behaviours were found consistently whatever the flow conditions and result in a negative linear correlation (Fig. 3c) between the two elemental ratios along the $>0.5 \%$ and $\leq 20 \%$ salinity range $(r=-0.884 ; P<0.0001)$. Beyond 20\% salinity, both $\mathrm{Sr}: \mathrm{Ca}$ and $\mathrm{Ba}: \mathrm{Ca}$ ratios do not seem to vary with salinity. As expected, a very high Sr:Ca ratio $\left(19.7 \pm 3.2 \times 10^{-3}\right)$ and relatively low $\mathrm{Ba}$ :Ca ratio $\left(21 \pm 19 \times 10^{-6}\right)$ were found at these high salinities (>20\%, Fig. $3 a$ and b). With the freshwater samples, lowest Sr:Ca ratios were encountered over a large range (Fig. 3a), varying from $2.08 \times 10^{-3}$ to $5.51 \times 10^{-3}$ and averaging $2.75 \pm 0.96 \times 10^{-3}$. On the contrary, the highest $\mathrm{Ba}: \mathrm{Ca}$ ratios were always found at the freshwater sites (Fig. $3 b$ ), $\geq 223 \times 10^{-6}$ with an average value of $404 \pm 68 \times 10^{-6}$. Whatever the situation no overlap between freshwater data and estuary data was found for the Sr:Ca ratio (Fig. 3a). As regards the Ba:Ca ratio (Fig. 3b), that of freshwater can sometimes be similar to that observed in low salinity $\left(0.5 \%\right.$ and $5 \%$ o) estuary water $\left(165-342 \times 10^{-6}\right)$. Nevertheless, the combined use of both $\mathrm{Sr}: \mathrm{Ca}$ and $\mathrm{Ba}: \mathrm{Ca}$ ratios seems to resolve the uncertainty of the $\mathrm{Ba}$ :Ca ratio at low salinity (Fig. 3c). There were too few water samples among sites to investigate possible difference in elemental ratios within the freshwater tributaries. The variability recorded on the tributary Gave de Pau (Fig. 3d) across almost an entire hydrological cycle (March to October 2007), was found to encompass the overall dispersion of $\mathrm{Ba}$ :Ca data including all freshwater sites (Fig. 3a, b). Sr:Ca ratios in water were found to be very stable over time in the Gave de Pau river.

\section{2. $\mathrm{Sr}: \mathrm{Ca}$ and $\mathrm{Ba}: \mathrm{Ca}$ continuous profiles in otoliths}

For all otoliths, high Sr:Ca and $\mathrm{Ba}: \mathrm{Ca}$ ratios $\left(\mathrm{Sr}: \mathrm{Ca}=10 \times 10^{-3} ; \mathrm{Ba}: \mathrm{Ca}=3.5 \times 10^{-6}\right.$ ) were observed in the central region corresponding to the leptocephalus stage from the core and $150 \mu \mathrm{m}$ out. These ratios decrease after the elver mark and is thought to be linked to the metamorphosis and the remobilization of element stock more than to the salinity occurring during this event (Otake et al., 1997) (Fig. 4), and thus cannot be used for habitat reconstitution. The latter is based on the elemental signature of the part out of the elver mark up to the otolith edge. This section represents 4 to 10 years according to age estimation. Femtoseconde laser scanning of eel otoliths revealed three main types of combined $\mathrm{Sr}$ and $\mathrm{Ba}$ profiles out of the elver mark. The first one was observed for all the individuals caught at the freshwater sites, which showed consistently low Sr:Ca mean ratios ranging 
from $0.94 \times 10^{-3}$ to $2.57 \times 10^{-3}$ with an average of $1.59 \times 10^{-3}$, and relatively high $\mathrm{Ba}: \mathrm{Ca}$ mean ratios comprised between $4.54 \times 10^{-6}$ and $21.8 \times 10^{-6}$ with an average of $12.1 \times 10^{-6}$ maintained throughout their life (Fig. 4a). Contrary to the Sr:Ca ratio which is relatively constant throughout the life of eels caught in freshwater sites, the $\mathrm{Ba}: \mathrm{Ca}$ ratio exhibited irregular variations, some eels showing a progressive decrease in the ratio with age while others presenting relatively constant or very fluctuating Ba:Ca ratios (Fig.4a). The two other types of profiles were only found in eels caught within the lower part of the estuary. $49 \%$ of yellow eels from this area showed a consistently high Sr:Ca mean ratio (from $4.78 \times 10^{-3}$ to $7.91 \times 10^{-3}$ with an average of $\left.6.45 \times 10^{-3}\right)$ and a low Ba:Ca mean ratio $\left(0.51 \times 10^{-6}\right.$ and $4.42 \times 10^{-6}$ with an average of $1.16 \times 10^{-6}$ ) after the elver mark (Fig. 4b). Elemental profiles of $51 \%$ of eels sampled in the estuary revealed large variations of both elements that would indicate a third pattern of life-history (Fig. 4c). For almost all eels of the third group, large variations observed for Sr:Ca ratios are characterised by a decrease of the ratio after the elver mark, then ratio remains stable for a period depending on the individual, two to four years according to age estimation, with values similar to those found in freshwater individuals. After this period, an increase of Sr:Ca ratio is observed until a ratio value corresponding to those described in the second profile (from $4.78 \times 10^{-3}$ to $7.91 \times 10^{-3}$ ) which is maintained until the sampling date. In very few eels, the Sr:Ca ratio exhibited multiple fluctuations between values found for freshwater and lower estuary sites. For all these individuals in the third group, Ba:Ca exhibits a strongly inverse relationship.

\subsection{Otolith mean ratios and water chemistry}

\subsubsection{Otolith vs ambient water}

Mean ratios cited above and calculated from elemental continuous profiles from the elver mark to the edge were compared to elemental mean ratios in water (Fig. 5). Otolith ratios from eel caught in freshwater sites were compared to the mean ratio given by all freshwater data of all freshwater sampling sites ( $\mathrm{Sr}: \mathrm{Ca}_{\text {water }}$ : $2.8 \pm 0.5 \times 10^{-3} ; \mathrm{Ba}: \mathrm{Ca}_{\text {water }}: 408.5 \pm 58.7 \times 10^{-6}$ ), whereas otolith ratios from eels caught in the estuary were compared to elemental mean ratios based on water data from the estuary (September 2007 and June 2008 ; Sr:Ca $a_{\text {water: }}$ 19.7 $\pm 1.6 \times 10^{-3}$; $\mathrm{Ba}: \mathrm{Ca}_{\text {water }}: 21.3 \pm 9.7 \times 10^{-6}$ ). The variability (standard deviation $\mathrm{SD}$ ) around the average ratio for each individual otolith was lower for $\mathrm{Sr}: \mathrm{Ca}$ in each end-member (SD averaging 20\%) compared to that observed for Ba:Ca (SD generally >30\%). The Mann-Whitney $U$-test confirmed a significant difference in $\mathrm{Sr}: \mathrm{Ca}$ and $\mathrm{Ba}: \mathrm{Ca}$ levels in otolith between strict estuary (salinity $>20)$ and freshwater sites $(P$ value of $\mathrm{Sr}: \mathrm{Ca}<0.007$ and $\mathrm{Ba}: \mathrm{Ca}<0.005)$, and reflected the observed water chemistry differences (Fig. 5).

\subsubsection{Partition coefficient}

Partition coefficients for $S r$ and $B a$, namely $D_{S r}$ and $D_{B a}$, characterised the relationship between otolith and the ambient water chemistry. Mean $D_{S r}$ and $D_{B a}$ differed slightly between freshwater and saltwater of the estuary, $0.49 \pm 0.24$ and $0.33 \pm 0.08$ for $\mathrm{Sr}$ and $0.036 \pm 0.024$ and $0.043 \pm 0.04$ for $\mathrm{Ba}$ respectively. Greater variability in $D_{B a}$ occurred as indicated by greater confidence intervals. Regarding 
the partition coefficient values for each site, the Gave de Pau site showed the lowest $D_{B a}$ of freshwater sites $(0.016 \pm 0.04)$ whereas the Termi site values were the highest $(0.040 \pm 0.011)$ contributing to the large variability observed for the overall $D_{B a}$ average for freshwater sites. Eels from St Laurent de Gosse showed a $D_{S r}$ $(0.314 \pm 0.042)$ similar to the estuary value although eels from Termi and the Gave de Pau river showed the highest values $(0.549 \pm 0.087$ and $0.438 \pm 0.089$ respectively). Slightly higher $D_{S r}$ mean in freshwater could indicate a more active uptake of Sr:Ca at low ambient Sr levels, or other sources of Sr than water.

\subsection{Sr:Ca and Ba:Ca association}

\subsubsection{Sr vs Ba in otolith for determination of environmental trend}

As $\mathrm{Sr}$ and $\mathrm{Ba}$ exhibit inverse relationship and otolith composition reflects $\mathrm{Sr}$ and $\mathrm{Ba}$ behaviours in water, mean $\mathrm{Ba}: \mathrm{Ca}$ ratios of individual otoliths were plotted versus $\mathrm{Sr}: \mathrm{Ca}$ in Figure 6 for all sampling sites. This approach indicates the dispersion of individuals according their $\mathrm{Sr}$ and $\mathrm{Ba}$ ratios reflecting the environmental signature and thus the environmental trend of their entire life. Furthermore, such an illustration aims to determine $\mathrm{Sr}: \mathrm{Ca}$ and $\mathrm{Ba}: \mathrm{Ca}$ limits which define a specific habitat characteristic (freshwater or saline or intermediate salinity). Three groups were identified. The first one includes the 67 eels caught in freshwater sites which are constrained within $4.54 \times 10^{-6}$ for the lowest $\mathrm{Ba}: \mathrm{Ca}$ ratio and $2.57 \times 10^{-3}$ for the highest Sr:Ca ratio. The second encompasses eels caught in the estuary and exhibiting a stable elemental otolith profile meaning no habitat change during the growing phase. These individuals show $\mathrm{Sr}: \mathrm{Ca}$ up to $5.90 \times 10^{-3}$ and $\mathrm{Ba}: \mathrm{Ca}$ ratios lower than $1.80 \times 10^{-6}$. These two first groups do not overlap and clearly distinguish eels which have a growing phase dominated by a freshwater habitat from eels which have a growing phase dominated by a saline environment. However, $51 \%$ of the eels caught in the estuary fall between these two distinct groups. These eels correspond to those showing a drastic change in elemental composition in the otolith matrix during the growing phase and constitute the third group.

\subsubsection{Check for vaterite disturbance}

For most of the ablated transects made from the nucleus to the opposite edge of the individual otolith, elemental ratio profiles do not show strong and simultaneous depletion of both elements suggesting that vaterite inclusions would be rather limited along the ablated sections. In addition, as illustrated on Figure 6, when $\mathrm{Sr}$ :Ca mean ratios in the otolith from freshwater eels do not really differ from the values found in the vaterite crystal sections of the same eel species (Tzeng et al., 2007), then the $\mathrm{Ba}: \mathrm{Ca}$ ratio is far from the ratio encountered in this carbonate polymorph. The reverse is also shown suggesting that otoliths in the present study do not suffer from inclusions such as vaterite. 


\section{5. $\mathrm{Sr}: \mathrm{Ca}$ and $\mathrm{Ba}: \mathrm{Ca}$ to reconstruct historical migrations}

Reconstruction of the history of eel habitat-use was conducted using the combination of both ratios in otoliths. Three assumptions were thus made based on observed ranges of $\mathrm{Sr} \mathrm{Ca}$ and $\mathrm{Ba}: \mathrm{Ca}$ ratios in otoliths, that would allow the interpretation of residency in the salt waters (estuary or coastal) or the freshwater environment of the Adour basin or migration between the two habitats for all eels irrespective of sampling location. The three assumptions are as follow:

(1) Background Sr:Ca ratios $<2.23 \times 10^{-3}$ (mean Sr:Ca background ratios of 67 eels caught in the freshwater catchment plus 2 S.D.) and Ba:Ca ratio $>4.84 \times 10^{-6}$ (mean $\mathrm{Ba}$ :Ca background ratios of 67 eels caught in the freshwater catchment minus 2 S.D) were considered as freshwater residency.

(2) Background Sr:Ca ratios $>4.93 \times 10^{-3}$ (mean Sr:Ca background ratios of 14 eels caught in the lower estuary minus 2 S.D.) and $\mathrm{Ba}: \mathrm{Ca}$ ratio $<3.2 \times 10^{-6}$ (mean $\mathrm{Ba}: \mathrm{Ca}$ background ratios of 14 eels caught in the lower estuary plus 2 S.D.) were considered as salt water residency with salinity $>20$, either in the coastal zone as in the lower estuary area.

(3) Otolith with intermediate $\mathrm{Sr}: \mathrm{Ca}$ and $\mathrm{Ba}: \mathrm{Ca}$ values, were regarded as having residence in the salinity gradient $(2-20)$ or associated to interhabitat shifters (see Fig. 4) moving from one environment to the other. In this latter case, each endmember signature could be recorded successively, if an eel resides long enough in each environment for the elemental ratio to be imprinted in detectable levels.

Based on the three assumptions defined above, life-history scans of the otolith, using simultaneous high resolution $\mathrm{Sr}: \mathrm{Ca}$ and $\mathrm{Ba}: \mathrm{Ca}$ ratios out of the elver mark, allowed three types of profiles to be distinguished. The first one was observed for all the individuals caught at the freshwater sites, which showed consistently low $\mathrm{Sr}: \mathrm{Ca}$ ratios and high $\mathrm{Ba}: \mathrm{Ca}$ ratios throughout their life (Fig. 4a). This pattern confirms that eels collected in the freshwater area of the Adour estuary did not subsequently move between fresh and salt waters throughout their life, but rather continuously resided in freshwater until the sampling date. The two other types of profiles were only found in eels caught within the lower part of the estuary. $49 \%$ of yellow eels from this area showed consistently high Sr:Ca ratio and low Ba:Ca ratio after the elver mark (Fig. 4b). Inversely to the previous type, this simultaneous $\mathrm{Sr}: \mathrm{Ca}$ and $\mathrm{Ba}: \mathrm{Ca}$ trend illustrates a permanent residency in the estuary at salinity $>$ 20 without ever entering freshwater. For the second half of the individual eels within the estuary, one drastic and simultaneous change in $\mathrm{Ba}$ and $\mathrm{Sr}$ ratio occurred. Indeed, a period of low Sr:Ca and high Ba:Ca ratios, corresponding to ratios observed for freshwater eels, appeared before a high $\mathrm{Sr}: \mathrm{Ca}$ and low $\mathrm{Ba}: \mathrm{Ca}$, similar to ratios found for eels from the Adour estuary (Fig. 4c).

\section{Discussion}

\subsection{Water and otolith chemistry}

There is a growing literature that explores the otolith microchemistry especially to distinguish populations or stocks, or to reconstruct migratory histories of fish (Campana, 1999). Nevertheless, spatial differences in elemental concentrations in waters have rarely been measured and are often derived from predictable relationships with salinity. Such relationships were used for Sr despite the fact that 
some freshwater locations may have water with Sr:Ca ratios close to or greater than seawater (Limburg, 1995; Wells et al., 2003; Kraus and Secor, 2004). In addition, limited emphasis has been placed on examining temporal variability (Elsdon et al., 2008) although $\mathrm{Ca}, \mathrm{Sr}$ and $\mathrm{Ba}$ are expected to regularly change in concentration within estuaries or coastal zones with different time-scales (day, week, month, season) (Elsdon and Gillanders, 2006) due to the interplay of several processes (tidal cycling, freshwater flow, flushing time ...). Indeed, the distribution of ambient $\mathrm{Ba}: \mathrm{Ca}$ along estuary gradients would be largely influenced by the release of Ba-enriched fluvial particles at low salinities in the upper estuary zone (Li and Chan, 1979; Coffey et al., 1997), benthic-water column fluxes (Colbert and McManus, 2005), mixing of fresh and salt water (Coffey et al., 1997; Elsdon and Gillanders, 2006) and uptake in association with biological activity (Guay and Falkner, 1998). In a recent review, Elsdon et al. (2008) insisted on the necessity of acquiring more knowledge of variability such as on factors influencing otolith chemistry, before elemental information recorded in the otolith can be used to accurately describe life history events and fish movement patterns.

In this study, spatial and temporal variability of water chemistry on Sr:Ca and $\mathrm{Ba}: \mathrm{Ca}$ ratios in the Adour estuary were investigated. The behaviour of $\mathrm{Sr}$ and $\mathrm{Ba}$ were clearly related to the salinity in accordance with other studies (Coffey et al., 1997; Guay and Falkner, 1998; Secor and Rooker, 2000; Howland et al., 2001; Kraus and Secor, 2004; Colbert and McManus, 2005; Moore and Shaw, 2008), resulting in relationships between $\mathrm{Sr}: \mathrm{Ca}$ and $\mathrm{Ba}: \mathrm{Ca}$ ratios and salinity. Nevertheless, such relationships appeared to be valid only for a salinity levels below $20 \%$. Within this salinity interval, clear close to linear relationships between $\mathrm{Sr}: \mathrm{Ca}$ (positive) and $\mathrm{Ba}: \mathrm{Ca}$ (negative) and salinity were defined whatever the flow regime (i.e. spring runoff and low flow periods).

A negative trend between $\mathrm{Ba}: \mathrm{Ca}$ and salinity was previously observed by Elsdon and Gillanders (2005b) but only for salinity above the Ba peak concentration expected at low to mid salinity and depending on the river flow, the suspended load and how compressed the salinity gradient is along the estuary (Coffey et al., 1997; Guay and Falkner, 1998; McCulloch et al., 2003; Moore and Shaw, 2008).We found significant variations in ambient Ba:Ca concentration (30 to $100 \mu \mathrm{mol} \mathrm{mol}{ }^{-1}$ ) at low salinities (0 - 10\%), but of a lesser magnitude to those observed by Elsdon and Gillanders (2005b) in southern Australian estuaries. Taking into account of the low turbidity of the Adour estuary and the $\mathrm{Ba}$ load measurements performed in both suspended particles from the fluvial zone, the estuary salinity gradient and the bed sediments within the estuary (Bareille, unpublished results), a limited release of $\mathrm{Ba}$ from fluvial particles towards the dissolved pool would be expected, leading to a reduced dissolved $\mathrm{Ba}$ peak at low salinity and thus less variability in the $\mathrm{Ba}: \mathrm{Ca}$ ratio. This is in agreement with the maximum dissolved Ba concentration (100-150 nmol $\mathrm{L}^{-1}$ ) measured at low salinities (0-10\%) in the Adour that occurred at a magnitude similar to the lower end-member found in the literature (Guay and Falkner, 1998). Concerning the freshwater end-member, relatively large variations were found apart from the average for both ratios. This variability can be related, for the Ba:Ca ratio, to the seasonal flow pattern and to weekly changes for which the cause is as yet unclear, while they appear to be more largely driven by seasonal scale for the Sr:Ca ratio, as previously found by Elsdon and Gillanders (2006). Part of the variability can be associated to underlying geology as well as processes influencing elemental concentrations in water (dilution, active binding to fluvial sediments, benthic-water fluxes...). In addition, lowest ambient $\mathrm{Ba}: \mathrm{Ca}$ concentrations from the freshwater end-member exhibited values that could 
overlap with those found in low salinity estuary water (0-5\%), confusing any attempt to distinguish freshwater occupancy from upper estuary occupancy of fish by using the otolith $\mathrm{Ba}$ :Ca ratio. Nevertheless, as no water Sr:Ca concentration overlapping was observed between freshwater and low salinity water in this study, one would expect that this limitation can therefore be resolved based on the simultaneous use of both $\mathrm{Ba}: \mathrm{Ca}$ and $\mathrm{Sr}: \mathrm{Ca}$ ratios. This is strongly supported by the distribution of $\mathrm{Sr}: \mathrm{Ca}$ and $\mathrm{Ba}: \mathrm{Ca}$ ratios in otolith, where these ratios show an interesting complementarity as shown in figure 6 (see below).

Beyond $20-25 \%$ salinity, both ratios did not vary according to the salinity. They remained almost constant as was observed in other systems (Kraus and Secor, 2004; Elsdon and Gillanders, 2005b), at values similar to normal seawater for the $\mathrm{Sr}: \mathrm{Ca}\left(18-20 \mu \mathrm{g} \mathrm{mg}^{-1}\right.$ ) and to Atlantic surface water for the Ba:Ca (around 5-11 $\mu \mathrm{g}$ $\mathrm{mg}^{-1}$ ) (Guay and Falkner, 1998). Some variations in the Ba:Ca ratio can be found in the 20-35 salinity interval but they appeared to be very small compared to the observed gradient between the two end-members. They are either due to isolated high peak concentrations of $\mathrm{Ba}$ or to higher global levels of dissolved $\mathrm{Ba}$ for some dates which may reflect changes in particulate load or difference in the mixtures of river inflow and marine end-member (Fry, 2002). Furthermore, it would imply that discriminating eels living in strict marine habitat (i.e., the coastal zone) from those living in the lower estuary (i.e., mixing zone corresponding to a salinity range between 20 - 30) would be more difficult with these two elemental ratios in the Adour estuary and along the Basque coast.

Our results clearly support the potential use of $\mathrm{Sr}: \mathrm{Ca}$ and $\mathrm{Ba}: \mathrm{Ca}$ ratios to trace freshwater and salt water environmental histories of eels and other fish inhabiting this estuary, but the simultaneous use of the two ratios seems to be strongly advised to resolve uncertainties especially regarding the Ba:Ca ratio. Similar trends in water and otolith ratios in our study were consistent with previous studies on other fish species confirming the growth evidence that incorporation of both $\mathrm{Sr}$ and $\mathrm{Ba}$ into otoliths is primarily driven by ambient concentrations (Bath et al., 2000; Milton and Chenery, 2001; Elsdon and Gillanders, 2004; Lin et al., 2007). Nevertheless, although freshwater displays around seven times less Sr:Ca and twenty times more $\mathrm{Ba}: \mathrm{Ca}$ than saltwater, we found that freshwater otoliths display around four times less $\mathrm{Sr}: \mathrm{Ca}$ and twelve times higher $\mathrm{Ba}: \mathrm{Ca}$ ratio than in the waters with salinity $>20$. This can be attributed to physiological regulations of elements at several biological interfaces (gills, intestine, inner ear membrane...) before they can be deposited into the crystallizing otolith (Campana, 1999). Several parameters can in fact affect elemental uptake through the gills (salinity, $\mathrm{pH}$, dissolved oxygen concentrations, hardness, temperature ...). Furthermore, geochemical processes in carbonate mineral precipitation may further influence element incorporation through competition or facilitation between elements (de Vries et al., 2005). Partition coefficients are subsequently used to describe the relationship between elemental concentrations in otolith and in the ambient water (Bath et al., 2000; Elsdon and Gillanders, 2003; Martin et al., 2004; Elsdon and Gillanders, 2005b). All partition coefficients in our study were below one, meaning that $\mathrm{Sr}: \mathrm{Ca}$ and $\mathrm{Ba}: \mathrm{Ca}$ ratios in otoliths were lower than those of the surrounding water. The overall $D_{S r}$ for freshwater $(0.49 \pm 0.24)$ was similar to those found by Wells et al. (2003) and De Vries et al. (2005). For saltwater, the overall $\mathrm{D}_{\mathrm{Sr}}$ $(0.33 \pm 0.08)$ was also in the range of 0.28 described by De Vries et al. (2005) and 
Elsdon and Gillanders (2005b), but slightly higher than coefficient found $\left(D_{S r}=\right.$ 0.18 ) by Kalish (1991) and Bath et al. (2000) in several marine fish species. We observed $\mathrm{D}_{\mathrm{Ba}}$ of $0.036 \pm 0.024$ and $0.043 \pm 0.04$, respectively in freshwater and saltwater, close to those cited for other species by Bath et al. (2000) in marine water and De Vries et al. (2005) and Wells et al. (2003) $\left(\mathrm{D}_{\mathrm{Ba}}=0.04\right)$ in freshwater. However these data were largely less than those found by Elsdon and Gillanders $(2005 b)\left(D_{\mathrm{Ba}}=0.136 \pm 0.005\right)$ in marine water for the black bream (Acanthopagrus butcheri).

Alternatively, $D_{S r}$ and $D_{B a}$ in this study present relatively large standard deviations especially for freshwater. This could be due first to the inter freshwater site heterogeneity in the partition coefficient values, and supported by the wide variability we encountered in $\mathrm{Ba}: \mathrm{Ca}$ and $\mathrm{Sr}: \mathrm{Ca}$ ratios of the otolith from the freshwater end-member (see Fig. 4). It is difficult to speculate the cause of this large variability as it can be linked to biological (sex, reproductive status, dietary sources, growth rates...) and kinetic effects. Bath et al. (2000), Elsdon and Gillanders (2005a) and De Vries et al. (2005), suggested an active incorporation of $\mathrm{Sr}$ and $\mathrm{Ba}$ at low ambient water ratios. It was proposed that changes in elemental discrimination would be linked to regulation of the amount of $\mathrm{Sr}$ and $\mathrm{Ba}$ transported in the endolymphatic fluid (Bath et al., 2000; Elsdon and Gillanders, 2003). The role of available binding sites on the calcite crystal surface was also suggested. At low ambient elemental concentrations, adsorption of elements may increase, while binding sites become saturated as elemental concentrations rise and equilibrium is reached in the solution interface and growing crystal surface (Watson, 1996). According Bath et al. (2000), $\mathrm{Sr}$ and $\mathrm{Ba}$ incorporation in fish otoliths were independent from growth rates of individual fish. No significant effect of temperature was found on Ba uptake (Bath et al., 2000; Elsdon and Gillanders, 2005a). Despite large seasonal temperature variations (from $6^{\circ} \mathrm{C}$ to $23^{\circ} \mathrm{C}$ ), eels in this study came from habitats geographically close to each other and thus underwent similar influence of temperature. As a result, this influence on otolith composition can be considered as negligible. A small proportion of elements probably originated from food sources (Limburg, 1995; Farrell and Campana, 1996; Gallahar and Kingsford, 1996). Walther and Thorrold (2006) recently highlighted the water as the major source of $\mathrm{Sr}$ and $\mathrm{Ba}$ with more than $83 \%$ and $95 \%$ respectively, in otoliths from juvenile mummichogs (Fundulus heteroclitus). Finally, we cannot exclude that some individual eels caught in the different freshwater areas did not move within several tributaries that could have had significant water $\mathrm{Ba}: \mathrm{Ca}$ and $\mathrm{Sr}: \mathrm{Ca}$ ratios. However, this does not affect the ability to recover significant differences in otolith ratios between contrasted fresh and seawater endmembers in the Adour estuary.

\subsection{Simultaneous use of strontium and barium to avoid vaterite disturbance}

Interpretations of chemical profiles along the otolith axis also rely on the presence of vaterite inclusions that could lead to misinterpretation of migratory history (Brown and Severin, 1999; Tzeng et al., 2007; Jessop et al., 2008). The occurrence of such inclusions was clearly demonstrated in several fish such as the European eel (Bowen Li et al., 1999; Brown and Severin, 1999; Tomas and Geffen 2003; Tzeng et al., 2007; Jessop et al., 2008; Morat et al., 2008). Chemical composition of vaterite inclusions in the otoliths were showed to be significantly 
different from the aragonite matrix as, fewer $\mathrm{Sr}: \mathrm{Ca}$ and $\mathrm{Ba}: \mathrm{Ca}$ ratios were measured in vaterite crystal than in aragonite of European and American eel otoliths (Jessop et al., 2008; Tzeng et al., 2007). The elemental differences between the two carbonate polymorphs can be attributed to the different coordination numbers of cations in substitution of $\mathrm{Ca}^{2+}$, limiting the entry of $\mathrm{Sr}, \mathrm{Ba}$ ions to the vaterite lattice while facilitating the entry of $\mathrm{Mg}$ and $\mathrm{Mn}$ during crystallisation (Tzeng et al., 2007), and resulting in systematically lower Sr:Ca and $\mathrm{Ba}: \mathrm{Ca}$ concentration ratios in vaterite than in aragonite. Sr:Ca ratios in otoliths of eels from freshwater sites on the Adour basin $\left(1.59 \pm 0.3210^{-3}\right)$ could be confused with average Sr:Ca ratio found within vaterite inclusions $\left(0.56 \times 10^{-3}-1 \times 10^{-3}\right)($ Tzeng et al., 2007; Jessop et al., 2008). Moreover, Ba:Ca ratios in vaterite crystal $\left(0.53 \pm 0.74 \times 10^{-6}\right)$ (Tzeng et al., 2007) did not really differ from ratios we found in otoliths from marine waters $\left(1.16 \pm 1.02 \times 10^{-6}-\mathrm{Fig}\right.$. 6). Using only the Sr:Ca ratio could lead to confusing vaterite signature with freshwater habitat signature, while using only $\mathrm{Ba}: \mathrm{Ca}$ could cause misinterpretation of vaterite composition as marine water habitat. However, combining both elemental signatures and profiles leads to the easy discrimination of such polymorph inclusion. In the absence of vaterite when one ratio is low (close to the ratio that can be confused with vaterite) the other may be high and vice versa, allowing the definitive differentiation of aragonite from the vaterite signal. According Tzeng et al. (2007), the percentage of otoliths of European eel with vaterite inclusions can be very high. 48\% of the 108 eels they analysed showed this type of inclusion and illustrates the necessity to distinguish vateritic profiles from aragonitic ones based on a relevant and easy tool. In the Adour estuary, the screening of the analysed otoliths carried out by optical microscopy confirmed the chemical results, which are the low occurrence of these inclusions in this area.

\subsection{Reconstruction of eel habitat-use.}

Otolith Sr:Ca ratio has been widely used to determine habitat discrimination and the reconstruction of the movements between freshwater and marine habitats of catadromous fish such as anguillids (Tsukamoto and Arai, 2001; Daverat et al., 2005; Arai and Hirata, 2006; Shiao et al., 2006). Conversely, Ba:Ca ratio has been largely unexplored in any fish species (Arai and Hirata, 2006; Hamer et al., 2006) in spite of its great promise (Bath et al., 2000; de Vries et al., 2005; Elsdon and Gillanders, 2005b; Gillanders, 2005). McCulloch et al. (2005) highlighted the sensitivity of the Sr:Ba otolith ratio to environment chemical signature especially for transitional environments such as estuaries. $\mathrm{Sr}$ and $\mathrm{Ba}$ levels in the otolith of barramundi (Lates calcarifer) leads to the determination of a mosaic of behaviours in terms of habitat use in this species. Our investigations on $\mathrm{Sr}: \mathrm{Ca}$ and $\mathrm{Ba}: \mathrm{Ca}$ profiles into eel otoliths of the Adour estuary, using laser ablation-ICP-MS, confirm the potential of both ratios to help distinguish the freshwater and seawater habitats of the eel and support the results obtained by Arai and Hirata (2006).

Previous studies (Feunteun et al., 2003), and especially those using Sr:Ca otolith microchemistry described different behaviours or tactics of habitat use within an eel population (Tsukamoto and Arai, 2001; Daverat et al., 2005). Three major contingents were defined for several eel populations coming from different water systems around the world: Europe (Daverat et al., 2005), Lithuanian and Baltic (Tzeng et al., 2000; Shiao et al., 2006), Asia (Tsukamoto and Arai, 2001; Tzeng et 
al., 2002), America (Jessop et al., 2002) and New Zealand (Arai et al., 2004): a river resident group, estuary and marine resident groups, and a last one with eels called "migrants", "transients" or "nomads" that moved from one habitat to another once or more during their growth phase. These three types of behaviour were also found in our study using only the Sr:Ca profiles provided by fs-LA-ICP-MS. However the same scheme and distribution of individuals were obtained with the $\mathrm{Ba}: \mathrm{Ca}$ profiles supporting the use of this ratio as a relevant marker for the discrimination of habitat use pattern on the Adour basin. Moreover, mean values of Sr:Ca ratios for each situation were in agreement with those found for European eels from other French watersheds (Daverat et al., 2005) and for Anguilla japonica (Tsukamoto and Arai, 2001; Tzeng et al., 2003; Arai and Hirata, 2006). Our conclusion on the $\mathrm{Ba}: \mathrm{Ca}$ ratio also supports the results of Elsdon and Gillanders (2005b) using $\mathrm{Ba}$ to trace the freshwater environmental histories of black bream (Acanthopagrus butcheri).

The presence of migrant eels was observed in European eels as in the other eel species like A. japonica (Tsukamoto and Arai, 2001; Tzeng et al., 2003), A. rostrata (Morrison et al., 2003; Jessop et al., 2006; Lamson et al., 2006), A. diffenbachii and $A$. australis (Arai et al., 2004). In the sampling group from the Adour Basin used to test the methodology, only one pattern of migration was observed, a downstream migration with a single drastic shift of habitat. This shift occurs after 2 to 4 years spent in freshwater. Daverat et al. (2005) observed this phenomenon for $91 \%$ of the migrants before age class 5 . In addition, Daverat et al. (2006) underlined the possibility of a size dependent migration for downstream nomads as the migration occurred in a similar range of age for all migrants. There was also evidence of upstream migratory behaviour, always with only one drastic change of habitat during the lifespan in the Gironde watershed (Daverat et al., 2005) as in Lithuanian waters (Shiao et al., 2006). For A. japonica (Tsukamoto and Arai, 2001) and $A$. australis in New Zealand (Arai et al., 2004), migratory behaviour with two drastic changes of habitats were also observed. In our study, only one eel from the estuary sampling exhibited a Sr:Ca profile showing regular variations within the range of estuary or marine water signature. This individual suggests that several migratory patterns could also be observed in the Adour estuary. The opportunistic sampling used in this study probably did not encompass all the migratory patterns especially those that are less frequent in the population. The absence of upstream migratory behavior as observed for $A$. japonica or $A$. australis may be due to the limited sampling in coastal zones near the Adour estuary. Moreover, the mobility of a group might be different according the species and the system considered. However, all the studies highlight the evidence of the semi catadromous life history of the eel. Furthermore, a large proportion of the eels caught in the downstream part of the Gironde and Adour estuaries exhibit a resident behaviour, 44\% (Daverat and Tomas, 2006) and 50\% (this study) respectively. In both studies, $100 \%$ of freshwater individuals were freshwater residents, illustrating also in the Adour Basin the decrease of migratory behaviour from the upstream river to marine environments. This was also observed in other systems for $A$. rostrata and $A$. japonica (Tsukamoto and Arai, 2001; Morrison and Secor, 2003).

\section{Conclusions}

In summary, a wide range of literature deals with the complexity of the interpretation of the otolith elemental signature, and the care that must be taken on 
all aspects of the links between environment and elemental composition, non biotic and biotic factors influencing elemental uptake and also variability of matrix structure. In this study, we illustrated the relevant use of $\mathrm{Sr}: \mathrm{Ca}$ and $\mathrm{Ba}: \mathrm{Ca}$ ratio chronology in the otolith in order to reconstruct the migratory history of the European eel avoiding misinterpretation due to a change in the otolith structure (vaterite inclusion) as well as reducing the uncertainty at low salinities by using the $\mathrm{Ba}$ : Ca ratio alone. Based on rigorous environmental monitoring, this combination can be a powerful tool for a better understanding and management of the habitat of interests for this declining species.

\section{Acknowledgments}

The authors are grateful to the National Water and Aquatic Environment Office (ONEMA) and MIGRADOUR for their help in the field logistics and fish sampling. Thanks to Pauline Pinel-Raffaitin for the saltwater Ba data. We would like to thank Aurélie Barats at the Chemical Institute, Nice University, for her help in water sampling and her suggestions that improved the quality of the paper. We also thank Rosy Cox, a native English speaker, for providing writing assistance that lead to the clarity and fluency of the English language, and the anonymous reviewers for helpful comments on the manuscript. This work was supported in the framework of the "Groupe De Recherche Adour" program sponsored by IFREMER, the University de Pau et des Pays de l'Adour and the CNRS. Hélène Tabouret acknowledges the Aquitaine Region and IFREMER for her doctoral fellowship.

\section{References}

Arai, T., Hirata, T. and Takagi, Y., 2007. Application of laser ablation ICPMS to trace the environmental history of chum salmon Oncorhynchus keta. Marine Environmental Research 63(1): 55-66.

Arai, T., Kotake, A., Lokman, P. M., Miller, M. J. and Tsukamoto, K., 2004. Evidence of different habitat use by New Zealand freshwater eels Anguilla australis and $A$. dieffenbachii, as revealed by otolith microchemistry. Marine Ecology Progress Series 266: 213-225.

Arai, T., and Hirata, T., 2006. Differences in the trace element deposition in otoliths between marine- and freshwater-resident Japanese eels, Anguilla japonica, as determined by laser ablation ICPMS. Environmental Biology of Fishes 75: 173-182. Barats, A., Pécheyran, C., Amouroux, D., Dubascoux, S., Chauvaud, L. and Donard, O. F. X., 2007. Matrix-matched quantitative analysis of trace-elements in calcium carbonate shells by laser-ablation ICP-MS: Application to the determination of daily scale profiles in scallop shell (Pecten maximus). Analytical and Bioanalytical Chemistry 387(3): 1131-1140.

Bath, G. E., Thorrold, S. R., Jones, C. M., Campana, S. E., McLaren, J. W. and Lam, J. W. H., 2000. Strontium and barium uptake in aragonitic otoliths of marine fish. Geochimica et Cosmochimica Acta 64(10): 1705-1714.

Berg, R., 1985. age determination of eels, Anguilla anguilla (L.): comparison of field data with otolith ring patterns. Journal of Fish Biology 26: 537-554. 
Bowen Ii, C. A., Bronte, C. R., Argyle, R. L., Adams, J. V. and Johnson, J. E., 1999. Vateritic sagitta in wild and stocked lake trout: Applicability to stock origin. Transactions of the American Fisheries Society 128(5): 929-938.

Brown, R. and Severin, K. P., 1999. Elemental distribution within polymorphic inconnu (Stenodus leucichthys) otoliths is affected by crystal structure. Canadian Journal of Fisheries and Aquatic Sciences 56(10): 1898-1903.

Campana, S. E., 1999. Chemistry and composition of fish otoliths: pathways, mechanisms and applications. Marine Ecology Progress Series 188: 263-297.

Campana, S. E. and Thorrold, S. R., 2001. Otoliths, increments, and elements: keys to a comprehensive understanding of fish populations? Canadian Journal of Fisheries and Aquaculture Sciences 58: 30-38.

Coffey, M., Dehairs, F., Collette, O., Luther, G., Church, T. and Jickells, T., 1997. The Behaviour of Dissolved Barium in Estuaries. Estuarine, Coastal and Shelf Science 45(1): 113-121.

Colbert, D. and McManus, J., 2005. Importance of seasonal variability and coastal processes on estuarine manganese and barium cycling in a Pacific Northwest estuary. Continental Shelf Research 25(11): 1395-1414.

Coutant, C.C, and Chen, C.H., 1993. Strontium microstructures in scales of freshwater and estuarine striped bass (Morone saxatalis) detected by laser ablation mass spectrometry. Canadian Journal of Fisheries and aquatic Sciences 50:1318-1323.

Daverat, F., Tomas, J., Lahaye, M., Palmer, M. and Elie, P., 2005. Tracking continental habitats shifts of eels using otolith $\mathrm{Sr} / \mathrm{Ca}$ ratios: validation and application to the coastal, estuarine and riverine eels of the Gironde-GaronneDordogne watershed. Marine and Freshwater Research 56: 619-627.

Daverat, F., and Tomas, J., 2006. Tactics and demographic attributes in the European eel Anguilla anguilla in the Gironde watershed, SW France. Marine Ecology Progress Series 307: 247-257.

de Vries, M. C., Gillanders, B. M. and Elsdon, T. S., 2005. Facilitation of barium uptake into fish otoliths: Influence of strontium concentration and salinity. Geochimica et Cosmochimica Acta 69(16): 4061-4072.

Dailloux, D., 2008. Video measurements of the Adour plume dynamic and its surface water optical characteristics. PhD thesis, University of Pau, $178 \mathrm{pp}$.

Elfman, M., Limburg, K. E., Kristiansson, P., Svedäng, H., Westin, L., Wickström, H., Malmqvist, K. and Pallon J., 2000. Complex life histories of fishes revealed through natural information storage devices: case studies of diadromous events as recorded by otoliths. Nuclear Instruments and Methods in Physics Research Section B: Beam Interactions with Materials and Atoms B 161-163: 877-881.

Elsdon, T. S. and Gillanders, B. M., 2003. Reconstructing migratory patterns of fish based on environmental influences on otolith chemistry. Reviews in Fish Biology and Fisheries 13(3): 219-235.

Elsdon, T. S. and Gillanders, B. M., 2004. Fish otolith chemistry influenced by exposure to multiple environmental variables. Journal of Experimental Marine Biology and Ecology 313(2): 269-284.

Elsdon, T. S., and Gillanders, B. M., 2005a. Alternative life-history patterns of estuarine fish: Barium in otoliths elucidates freshwater residency. Canadian Journal of Fisheries and Aquatic Sciences 62(5): 1143-1152.

Elsdon, T. S. and Gillanders, B. M., 2005b. Consistency of patterns between laboratory experiments and field collected fish in otolith chemistry: An example and applications for salinity reconstructions. Marine and Freshwater Research 56(5): 609-617. 
Elsdon, T. S., and Gillanders, B. M., 2006. Temporal variability in strontium, calcium, barium, and manganese in estuaries: Implications for reconstructing environmental histories of fish from chemicals in calcified structures. Estuarine, Coastal and Shelf Science 66(1-2): 147-156.

Elsdon, T. S., Wells, B.K., Campana, S.E., Gillanders B.M., Jones, C.M., Limburg, K.E., Secor, D.H., Thorrold, S.R., Walther, B.D., 2008. Otolith chemistry to describe movements and life-history parameters of fishes: hypotheses, assumptions, limitations and inferences. Oceanography and Marine Biology: An annual Review 46: 297-330.

Farrell, J., Campana, S.E., 1996. Regulation of Calcium and Strontium Deposition on the Otoliths of Juvenile Tilapia, Oreochromis niloticus. Comparative Biochemistry and Physiology 115A(2): 103-109.

Feunteun, E., Lafaille, F., Robinet, T., Briand, C., Baisez, A., Olivier, J.-M., Acou, Antony, 2003. A Review of Upstream Migration and Movements in Inland Waters by Anguillid Eels: Toward a General Theory. In Eel Biology. Edited by Aida, K., Tsukamoto, K., Yamauchi, K. Springer-Verlag, Tokyo, pp. 191-213.

Fry, B., 2002. Conservative mixing of stable isotopes across estuarine salinity gradients: a conceptual framework for monitoring watershed influences on downstream fisheries production. Estuaries 25 (2): 264-271.

Gallahar, N. K. and Kingsford, M. J., 1996. Factors influencing Sr/Ca ratios in otoliths of Girella elevata: An experimental investigation. Journal of Fish Biology 48(2): 174-186.

Gillanders, B. M., 2005. Otolith chemistry to determine movements of diadromous and freshwater fish. Aquatic Living Resources 18(3): 291-300.

Guay, C. K. and Falkner, K. K., 1998. A survey of dissolved barium in the estuaries of major Arctic rivers and adjacent seas. Continental Shelf Research 18(8): 859882.

Halden, N. M., Mejia, S. R., Babaluk, J. A., Reist, J. D., Kristofferson, A. H., Campbell, J. L. and Teesdale, W. J., 2000. Oscillatory zinc distribution in Arctic char (Salvelinus alpinus) otoliths: The result of biology or environment? Fisheries Research 46(1-3): 289-298.

Hamer, P. A., Jenkins, G. P. and Coutin, P., 2006. Barium variation in Pagrus auratus (Sparidae) otoliths: A potential indicator of migration between an embayment and ocean waters in south-eastern Australia. Estuarine, Coastal and Shelf Science 68(3-4): 686-702.

Howland, K. L., Tonn, W. M., Babaluk, J. A. and Tallman, R. F., 2001. Identification of freshwater and anadromous inconnu in the Mackenzie River system by analysis of otolith strontium. Transactions of the American Fisheries Society 130(5): 725741.

Jessop, B. M., Shiao, J. C., lizuka, Y. and Tzeng, W. N., 2002. Migratory behaviour and habitat use by American eels Anguilla rostrata as revealed by otolith microchemistry. Marine Ecology Progress Series 233: 217-229.

Jessop, B. M., Shiao, J. C., lizuka, Y. and Tzeng, W. N., 2006. Migration of juvenile American eels Anguilla rostrata between freshwater and estuary, as revealed by otolith microchemistry. Marine Ecology Progress Series 310: 219-233.

Jessop, B. M., Shiao, J. C., lizuka, Y., Tzeng, W. N., 2008. Prevalence and intensity of occurence of vaterite inclusion in aragonite otoliths of American eels Anguilla rostrata. Aquatic Biology 2: 171-178.

Jones, C. and Chen, Z., 2003. New techniques for sampling larval and juvenile fish otoliths for trace-element analysis with laser-ablation sector-field inductivelycoupled-plasma mass spectrometry (SF-ICP-MS). The Big Fish Bang 431-443. 
Kalish, J. M., 1991. Determinants of otolith chemistry: seasonal variation in the composition of blood plasma, endolymph and otoliths of bearded rock cod Pseudophycis barbatus. Marine Ecology Progress Series 74(2-3): 137-159.

Kraus, R. T. and Secor, D. H., 2004. Incorporation of strontium into otoliths of an estuarine fish. Journal of Experimental Marine Biology and Ecology 302(1): 85-106. Lamson, H. M., Shiao, J. -C., Lizuka, Y., Tzeng, W. -N., and Cairns, D. H.. 2006. Movement patterns of American eels (Anguilla rostrata) between salt and fresh water in a coastal watershed, based on otolith microchemistry. Marine Biology 149: 1567-1576.

Li, Y. H. and Chan, L. H., 1979. Desorption of Ba and 226Ra from river-borne sediments in the Hudson estuary. Earth and Planetary Science Letters 43: 343350.

Limburg, K. E., 1995. Otolith strontium traces environmental history of subyearling American shad Alosa sapidissima. Marine Ecology Progress Series 119(1-3): 2536.

Limburg, K. E., Landergren, P., Westin, L., Elfman, M. and Kristiansson, P., 2001. Flexible modes of anadromy in Baltic sea trout: Making the most of marginal spawning streams. Journal of Fish Biology 59(3): 682-695.

Lin, S.-H., Chang, C.-W., lizuka, Y. and Tzeng, W.-N., 2007. Salinities, not diets, affect strontium/calcium ratios in otoliths of Anguilla japonica. Journal of Experimental Marine Biology and Ecology 341(2): 254-26

Martin, G. B., Thorrold, S. R. and Jones, C. M., 2004. Temperature and salinity effects on strontium incorporation in otoliths of larval spot (Leiostomus xanthurus). Canadian Journal of Fisheries and Aquatic Sciences 61(1): 34-42.

McCulloch, M., Fallon, S., Wyndham, T., Hendy, E., Lough, J. and Barnes, D., 2003. Coral record of increased sediment flux to the inner Great Barrier Reef since European settlement. Nature 421(6924): 727-730.

McCulloch, M., Cappo, M., Aumend, J., Müller, W., 2005. Tracing the life history of individual barramundi using laser ablation MC-ICP-MS Sr-isotopic and Sr/Ba ratios in otoliths. Marine and Freshwater Research 56: 637-644.

Melancon, S., Fryer, B. J., Ludsin, S. A., Gagnon, J. E. and Yang, Z., 2005. Effects of crystal structure on the uptake of metals by lake trout (Salvelinus namaycush) otoliths. Canadian Journal of Fisheries and Aquatic Sciences 62(11): 2609-2619.

Milton, D. A., and Chenery, Simon R., 2001. Sources and uptake of trace metals in otoliths of juvenile barramundi (Lates calcarifer). Journal of Experimental Marine Biology and Ecology 264(1): 47-65.

Milton, D., Halliday, I., Sellin, M., Marsh, R., Staunton-Smith, J. and Woodhead, J., 2008. The effect of habitat and environmental history on otolith chemistry of barramundi Lates calcarifer in estuarine populations of a regulated tropical river. Estuarine, Coastal and Shelf Science 78(2): 301-315.

Moore, W. S. and Shaw, T. J., 2008. Fluxes and of radium isotopes, barium, and uranium in seven Southeastern US rivers and estuaries. Marine Chemistry 108(34): 236-254.

Morat, F., Betoulle, S., Robert, M., Thailly, A. F., Biagianti-Risbourg, S. and Lecomte-Finiger, R., 2008. What can otolith examination tell us about the level of perturbations of Salmonid fish from the Kerguelen Islands? Ecology of Freshwater Fish 17(4): 617-627.

Morrison, W. E. and Secor, D. H., 2003. Demographic attributes of yellow-phase American eels (Anguilla rostrata) in the Hudson River estuary. Canadian Journal of Fisheries and Aquatic Sciences 60(12): 1487-1501.

Morrison, W. E., Secor, D. H., and Piccoli, P. M., 2003. Estuarine habitat use by Hudson River American eels as determined by otolith strontium: calcium ratios. Pages 87-99 in D. 
A. Dixon, editor. Biology, management, and protection of catadromous eels. American Fisheries Society, Symposium 33, Bethesda, Maryland.

Morse, J. W. and Bender, M. L., 1990. Partition coefficients in calcite: Examination of factors influencing the validity of experimental results and their application to natural systems. Chemical Geology 82: 265-277.

Otake, T., Ishii, T., T., I., Nakahara, M. and Nakamura, R., 1997. Changes in otolith strontium:calcium ratios in metamorphosing Conger myrisaster leptocephali. Marine Biology 128: 565-572.

Panfili, J., Pontual (de), H., Troadec, H., Wright, P.J. (ed), 2002. Manual of fish sclerochronology. Ifremer-IRD, Rennes.

Point, D., Bareille, G., Stoichev, T., Etcheber, H., Amouroux, D. and Donard, O. F. X., 2007. Reactivity, Interactions and Transport of Trace Elements, Organic Carbon and Particulate Material in a Mountain Range River System (Adour River, France) Journal of Environmental Monitoring 9(157-167.

Secor, D. H. and Rooker, J. R., 2000. Is otolith strontium a useful scalar of life cycles in estuarine fishes? Fisheries Research 46(1-3): 359-371.

Shiao, J. C., Lozys, L., lizuka, Y. and Tzeng, W. N., 2006. Migratory patterns and contribution of stocking to the population of European eel in Lithuanian waters as indicated by otolith Sr:Ca ratios. Journal of Fish Biology 69(3): 749-769.

Svedang, H., Wickstrom, H., Reizenstein, M., Holmgren, K., Florenius, P., 1998. Accuracy and precision in eel age estimation, using otoliths of known and unknown age. Journal of Fish Biology 53: 456-464.

Tomas, J. and Geffen, A. J., 2003. Morphometry and composition of aragonite and vaterite otoliths of deformed laboratory reared juvenile herring from two populations. Journal of Fish Biology 63(6): 1383-1401.

Tsukamoto, K., and Arai, T., 2001. Facultative catadromy of the eel Anguilla japonica between freshwater and seawater habitats. Marine Ecology Progress Series 220: 265-276.

Tzeng, W.-N., lizuka, Y., Shiao, J.-C., Yamada, Y. and Oka, H. P., 2003. Identification and growth rates comparison of divergent migratory contingents of Japanese eel (Anguilla japonica). Aquaculture 216(1-4): 77-86.

Tzeng, W. N., Chang, C. W., Wang, C. H., Shiao, J. C., lizuka, Y., Yang, Y. J., You, C. F., Lozys, L., 2007. Misidentification of the migratory history of anguillid eels by Sr/Ca ratios of vaterite otoliths. Marine Ecology Progress Series 348: 285295.

Tzeng, W. N., Severin, K. P., Wickström, H., 1997. Use of otolith microchemistry to investigate the environmental history of European eel Anguilla anguilla. Marine Ecology Progress Series 149(1-3): 73-81.

Tzeng, W. N., Shiao, J. C., lizuka, Y., 2002. Use of otolith Sr:Ca ratios to study the riverine migratory behaviors of Japanese eel Anguilla japonica. Marine Ecology Progress Series 245: 213-221.

Tzeng, W. N., Wang, C. H., Wickström, H., Reizenstein, M., 2000. Occurrence of the semi-catadromous European eel Anguilla anguilla in the Baltic Sea. Marine Biology 137(1): 93-98.

Walther, B. D., and Thorrold, S.R., 2006. Water, not food, contributes the majority of strontium and barium deposited in the otoliths of a marine fish. Marine and Freshwater Research 311: 125-130.

Watson, E. B., 1996. Surface enrichment and trace-element uptake during crystal growth. Geochimica et Cosmochimica Acta 60(24): 5013-5020.

Wells, B. K., Rieman, B. E., Clayton, J. L., Horan, D. L. and Jones, C. M., 2003. Relationships between water, otolith, and scale chemistries of westslope cutthroat 
trout from the Coeur d'Alene River, Idaho: The potential application of hard-part chemistry to describe movements in freshwater. Transactions of the American Fisheries Society 132(3): 409-424.

Wyndham, T., McCulloch, M., Fallon, S., Alibert, C., 2004. High resolution coral records of rare earth elements in coastal seawater: Biogeochemical cycling and a new environmental proxy. Geochimica et Cosmochimica Acta 68: 2067-2080.

Yoshinaga, J., Nakama, A., Morita, M. and Edmonds, J. S., 2000. Fish otolith reference material for quality assurance of chemical analyses. Marine Chemistry 69(1-2): 91-97.

\section{Figures}

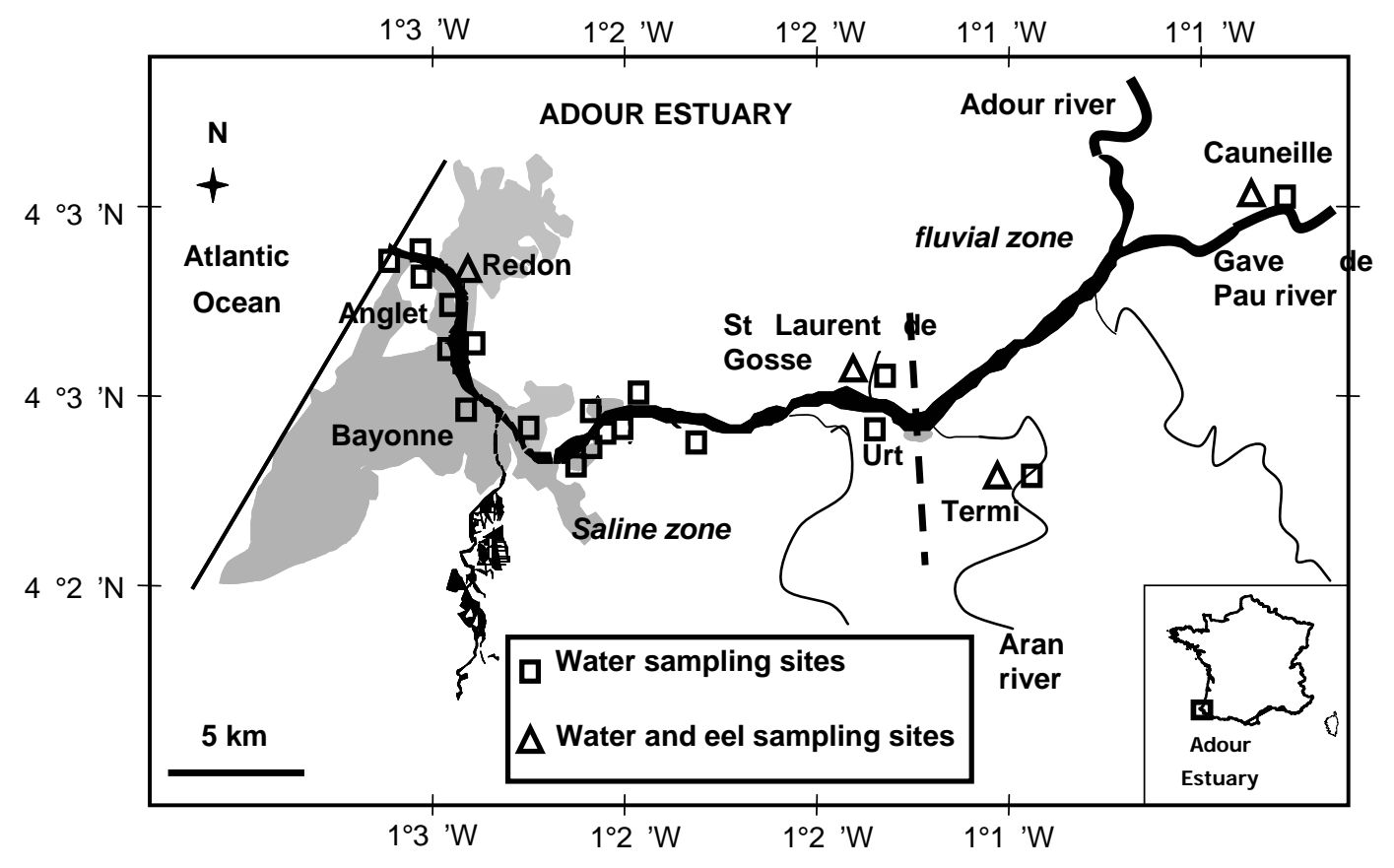

Figure 1: Map of the Adour basin showing the sampling sites for water (square) and yellow eels (triangle). Dotted line: Limit of the saline tide influence. 


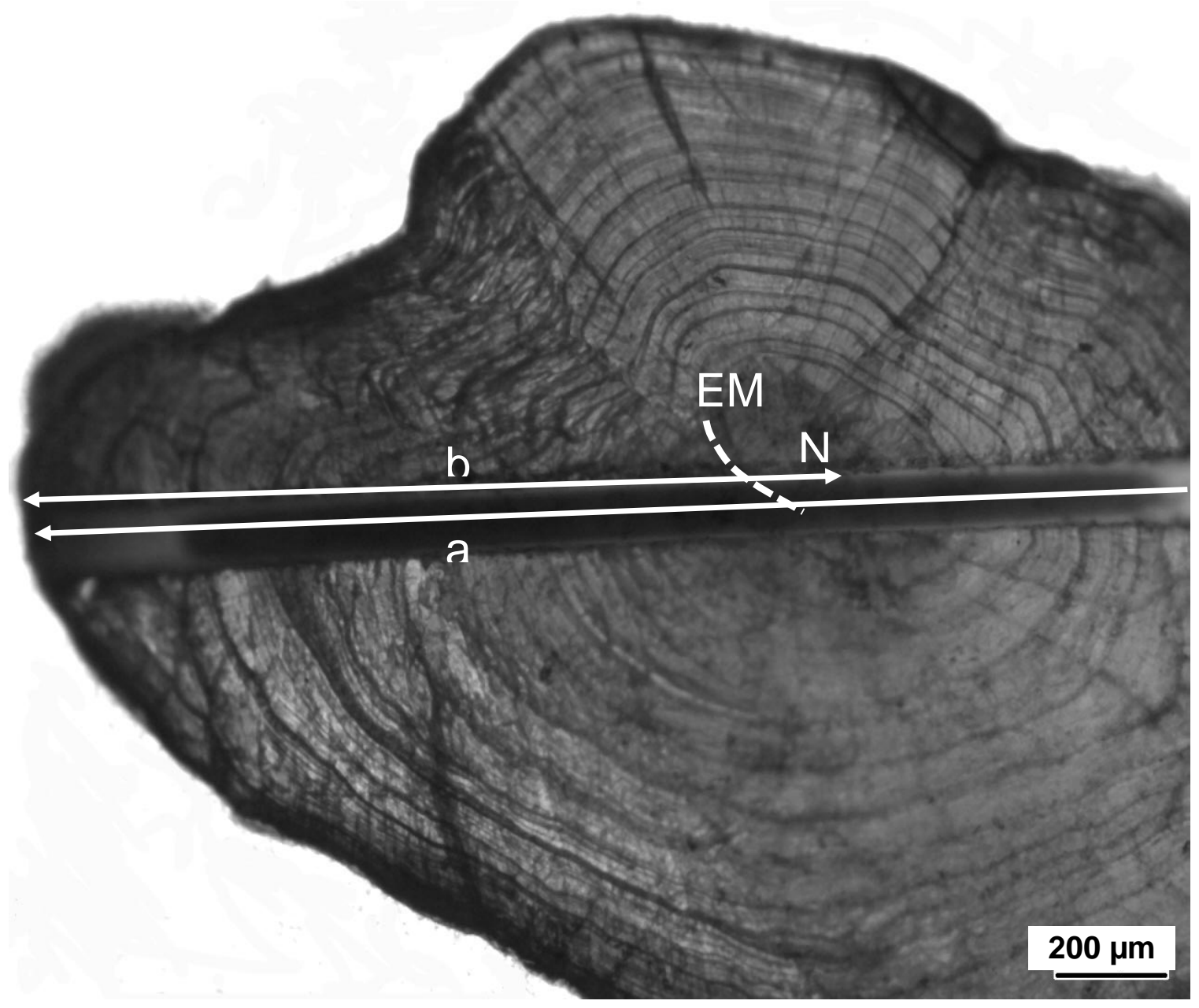

Figure 2: Otolith of yellow European eel $(33.6 \mathrm{~cm}$ total length, age estimated 8 years) from freshwater site showing the entire continuous transect made by fs-LA-ICP-MS (a) from the edge to the other, and the section used for analysis (double arrows, b). EM: elver mark; N: nucleus. 

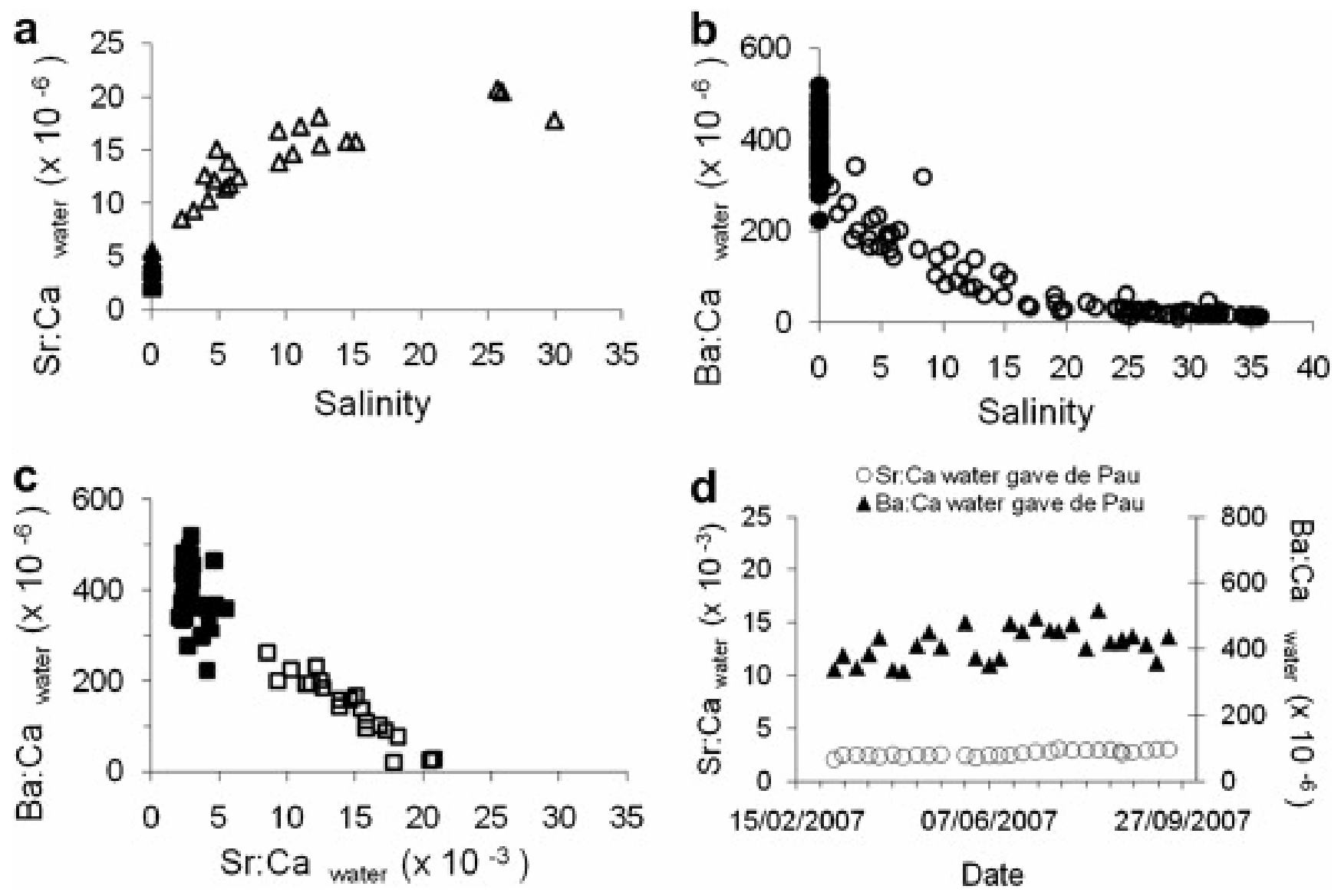

Figure 3: Relationship between element: $\mathrm{Ca}$ ratio in water of the Adour estuary and salinity: Sr:Ca ratio (a), Ba:Ca ratio (b), relationship between $\mathrm{Ba}: \mathrm{Ca}$ and $\mathrm{Sr}: \mathrm{Ca}$ ratios (c), and temporal evolution of $\mathrm{Sr}: \mathrm{Ca}$ and $\mathrm{Ba}: \mathrm{Ca}$ ratios along 2007 in the Gave de Pau river (d). Filled symbols represent samples with salinity $<0.5 \%$, whereas open symbols consist of saline water $(>0.5 \%)$ in figure $3 a), 3 b)$ and $3 c)$. 

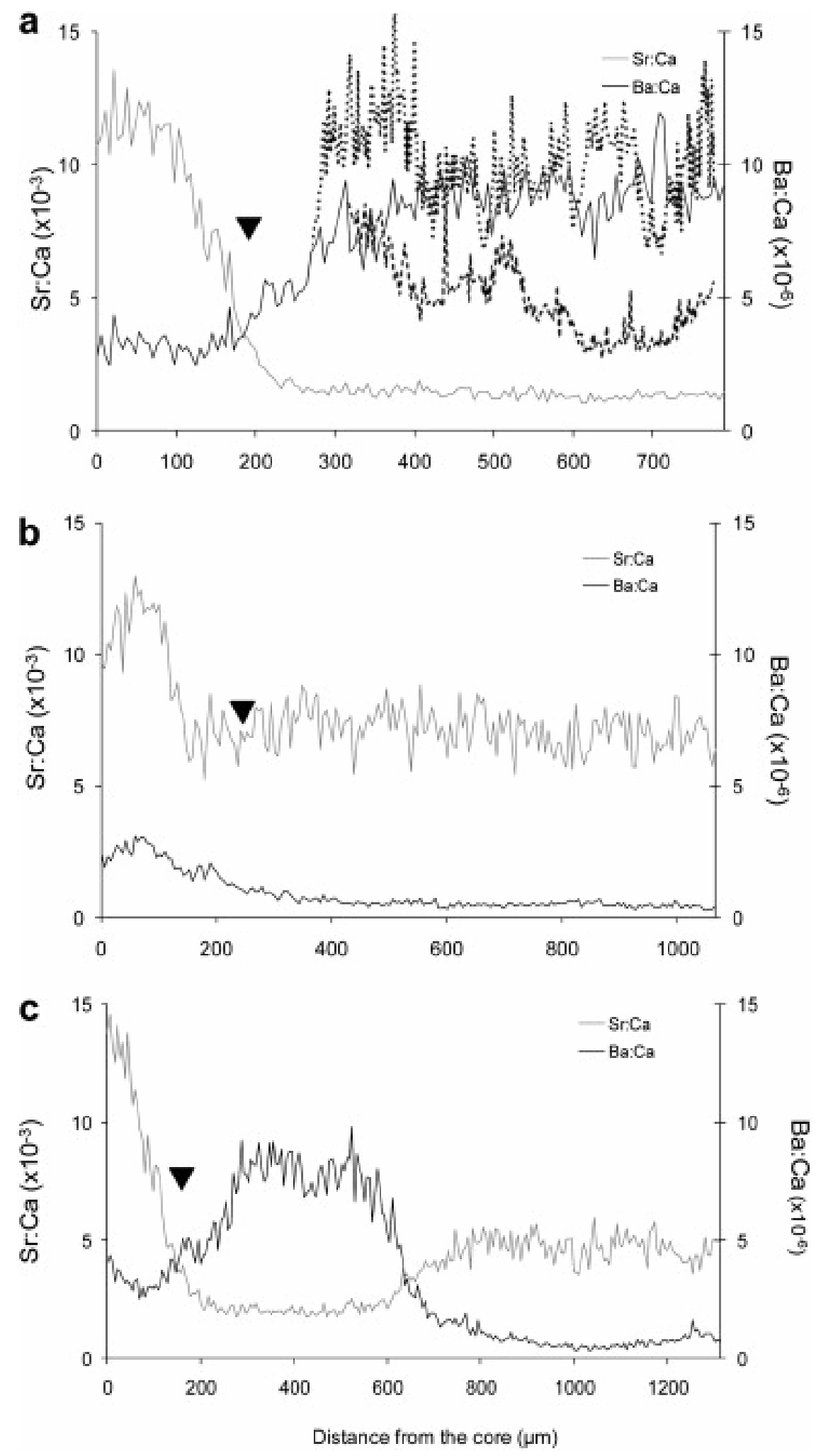

Figure 4: Continuous profiles showing the evolution of $\mathrm{Sr}: \mathrm{Ca}$ (grey line) and $\mathrm{Ba}: \mathrm{Ca}$ (black line) ratios $\left(\mu \mathrm{g} \cdot \mathrm{g}^{-1}\right)$ in otoliths of a) an eel caught in freshwater b) an eel caught in the estuary without drastic change in element ratios c) 
an eel caught in the estuary with a drastic change in element ratios $\boldsymbol{\nabla}$ : elver mark. Because the high variability in the $\mathrm{Ba}$ :Ca ratio out of the elver mark, the three main types of profiles are shown in figure 4a.
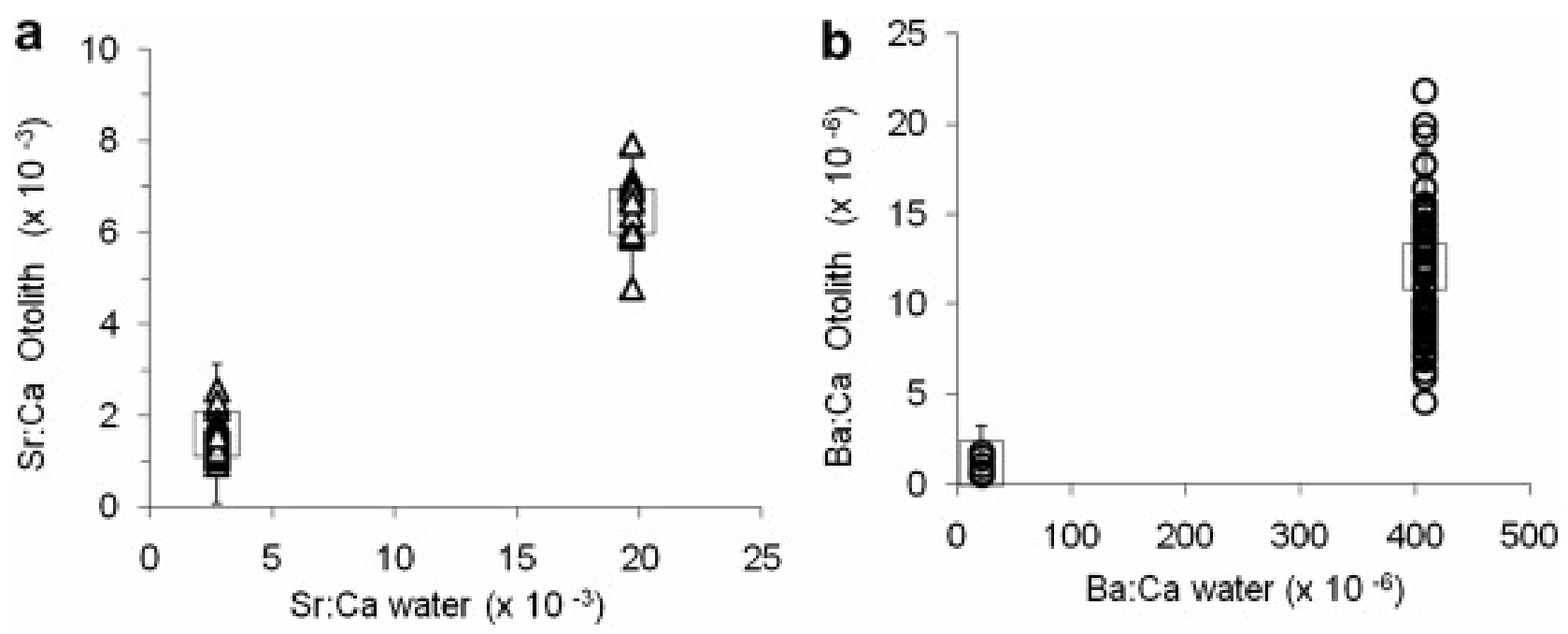

Figure 5: Relationship between Sr:Ca ratio in otolith and Sr:Ca in water (a), $\mathrm{Ba}: \mathrm{Ca}$ ratio in otolith and $\mathrm{Ba}: \mathrm{Ca}$ in water (b). Grey dots are individual otolith background data, open square are mean ratios with $95 \% \mathrm{Cl}$ illustrated by a double bar. 


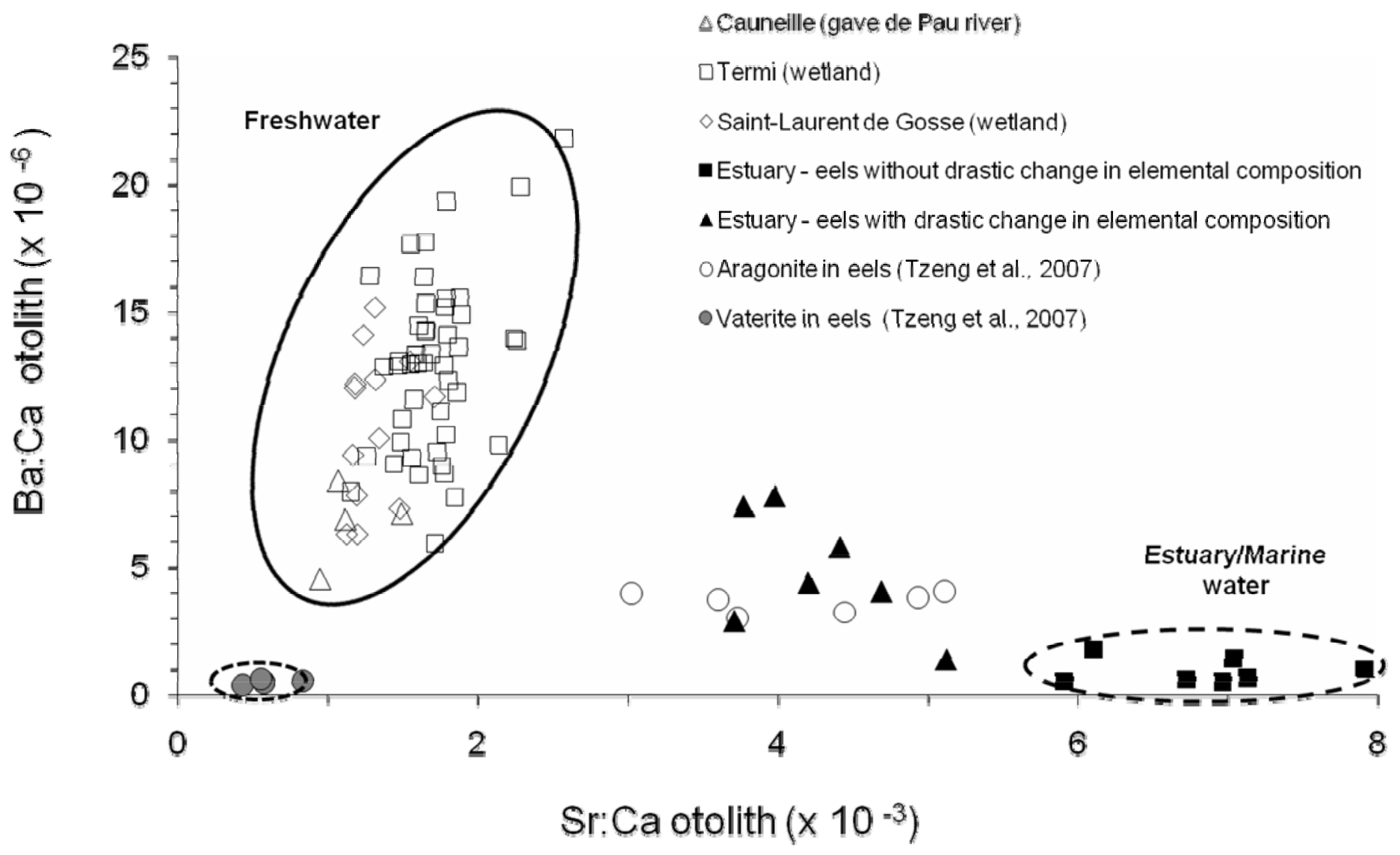

Figure 6: Relationship between $\mathrm{Sr}: \mathrm{Ca}$ ratio and $\mathrm{Ba}: \mathrm{Ca}$ in otolith of eel Anguilla anguilla from the Adour estuary (filled square and triangle) and associated watersheds (open rhombus, triangle and square). Ratios found in the same species by Tzeng et al. (2007) in both aragonite (open circle) and vaterite (filled circle) otolith microstructures are also shown for comparison. 
Tables

Table 1: Operating conditions of the fs-LA-ICP-MS

\begin{tabular}{|c|c|}
\hline \multicolumn{2}{|l|}{ Laser ablation } \\
\hline $\begin{array}{l}\text { Instrumentation } \\
\text { Wavelength } \\
\text { Repetition rate } \\
\text { Energy } \\
\text { Sampling strategies } \\
\text { Platine speed } \\
\text { Scan speed }\end{array}$ & $\begin{array}{l}\text { Femtolaser (Alfamet - Novalase, France) } \\
1030 \mathrm{~nm} \\
500 \mathrm{~Hz} \\
31 \mu \mathrm{J} \text { pulse-1 } \\
\text { Linear raster scan } \\
50 \mu \mathrm{m} \mathrm{s}^{-1} \text { (pre-ablation), } 5 \mu \mathrm{m} \mathrm{s}^{-1} \text { (ablation) } \\
1000 \mu \mathrm{m} \mathrm{s}^{-1} \text { (pre-ablation and ablation) }\end{array}$ \\
\hline ICP-MS & \\
\hline $\begin{array}{l}\text { Instrumentation } \\
\text { Dual sample introduction system } \\
\text { Torch } \\
\text { Nebulizer } \\
\text { Spray Chamber } \\
\text { Coolant gas flow (Ar) } \\
\text { Auxiliary gas flow (Ar) } \\
\text { Nebulizer gas flow }(\mathrm{He}) \\
\text { Isotopes and Dwell time (ms) } \\
\text { Internal standard (m/z) }\end{array}$ & 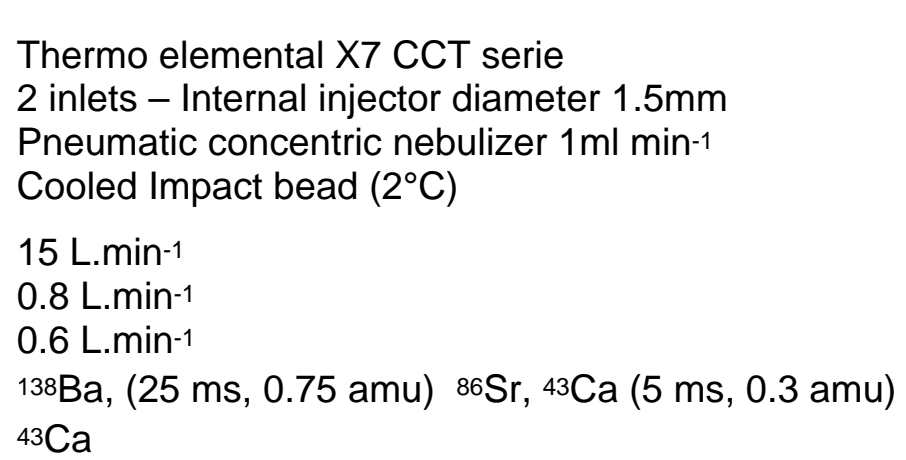 \\
\hline
\end{tabular}

